\title{
KOBİ’lerin Endüstri 4.0 Hazırlık Süreci: Bir Meta-Sentez Çalışması
}

\section{The Industry 4.0 Preparation Process of SMEs: A Meta-Synthesis Study}

\author{
Dr. Öğr. Üyesi Meral ÇALIȘ DUMAN ${ }^{(D)}$,
}

\section{Öz}

Endüstri 4.0 veya Dördüncü Sanayi Devrimi bugün adını sıklıkla duyduğumuz, etki alanı oldukça kapsaml, bir teknolojik devrimdir. Kelime olarak, bilgi ve iletişim teknolojilerin üretim alanında kullanılması anlamına gelmektedir. Endüstri 4.0, fiziksel sistemlerin, sanal ortama taşınarak, fiziksel dünya ile siber dünyanın entegrasyonun sağlanmasıdır. Endüstri 4.0, sosyal, ekonomik, kültürel ve teknolojik alanlarda önemli etkileri olmakla birlikte, tanımından da anlaşılacağı üzere, en büyük etkiyi sanayi ve üretim alanında yaratmıştır. Bu nedenle, üretim odaklı işletmelerin Endüstri 4.0 konseptine geçiş süreçleri öncelik taşımaktadır. Büyük ölçekli işletmelere nazaran KOBİ'lerin Endüstri 4.0'a geçişi, sermaye, nitelikli personel ve bilgi eksikliklerinden dolayı daha zordur. Ülkemiz işletmelerinin \%1'i büyük ölçekli işletmelerden oluşmaktadır. Bunun yanı sıra, işletmelerin \%99'unun KOBİ olduğu düşünüldüğünde, KOBİ'lerin Endüstri 4.0'a geçmeleri ve bunun için gerekli tedbirlerin alınması önem taşımaktadır. Türkiye ekonomisinin bel kemiğini oluşturan KOBI'lerin Endüstri 4.0'a geçişi kritik düzeydedir. Bu konuda hem uygulamada hem de akademik konularda boşluk bulunmaktadır. $\mathrm{Bu}$ araştırmada, bu boşluğu doldurmak amacıyla Endüstri 4.0 ve KOBI'ler konusunda ilgili literatür incelenmiş ve bir meta-sentez çalışma yapılmıştır. KOBİ'ler için yol haritaları ve Endüstri 4.0 geçiş modelleri üzerine incelemeler ortaya konmuştur. Bu bağlamda Endüstri 4.0' geçiş sürecinde KOBI'lerin planlamaları ve süreçten elde edecekleri faydalar karşılaş̧ırmalı olarak ele alınmıştır.

Anahtar Kelimeler: Endüstri 4.0, dördüncü sanayi devrimi, endüstri 4.0 teknolojileri, KOBİ

Makale Türü: Araştırma

\begin{abstract}
Industry 4.0, or the Fourth Industrial Revolution, is a technological revolution that we hear often today, with a very extensive domain. As a word, it means the use of information and communication technologies in the field of production. Industry 4.0 is the integration of physical systems with the cyber world by moving them to the virtual environment. Although Industry 4.0 has significant effects in social, economic, cultural and technological areas, as can be understood from its definition, it has created the greatest impact in the field of industry and production. For this reason, the transition processes of production-oriented enterprises to the Industry 4.0 concept have priority. SMEs' transition to Industry 4.0 compared to large-scale enterprises is more difficult due to lack of capital, qualified personnel and information. $1 \%$ of our country's businesses consist of large-scale enterprises. In addition, when it is considered that $99 \%$ of the enterprises are SMEs, it is important for SMEs to switch to Industry 4.0 and to take the necessary measures for this. Industry 4.0 transition of SMEs form the backbone of Turkey's economy is critical. There is a gap in this regard both in practice and in academic matters. In this research, in order to fill this gap, the relevant literature on Industry 4.0 and SMEs was examined and a meta-synthesis study was conducted. Studies on road maps and Industry 4.0 transition models for SMEs have been put forward. In this context, the planning of SMEs in the transition process to Industry 4.0 and the benefits they will gain from the process are discussed comparatively.
\end{abstract}

Keywords: Industry 4.0, Fourth Industrial revolution, industry 4.0 technologies, SME

Paper Type: Research

${ }^{1}$ Malatya Turgut Özal Üniversitesi, Akçadağ MYO, meral.duman@ozal.edu.tr.

Atıf için (to cite): Çslış Duman, M. (2021). Kobi’lerin endüstri 4.0 hazırlık süreci: Bir meta-sentez çalışması. Afyon Kocatepe Üniversitesi Sosyal Bilimler Dergisi, 23(2), 624-641. 


\section{Giriş}

Endüstri 4.0 (E4.0) veya Dördüncü Sanayi Devrimi bugün tüm dünyanın ve Türkiye'nin en önemli gündem maddelerinden biridir. Geçmişten günümüze, teknolojik alanda, hayal etmekte zorlandığımız gelişmelerin gerçek olduğu, teknolojik dönüşümlerin ülkeleri, ekonomileri ve insanların yaşayış şekillerini değiştirdiği bilinen bir gerçektir. Geçmişten günümüze her dönemde ayrı bir teknolojik değişim dünyaya yön vermiştir. Bugün ise adından en fazla söz ettiren, kimi bilim insanlarınca bir felsefe, kimilerince, bir teknoloji, kimilerince bir vizyon olarak nitelenen E4.0 dünyayı etkilemektedir. Kavramı ilk ortaya atan Alman bilim insanlarınca E4.0, bir vizyondur (Gilchrist, 2016). İşletmelerin ulaşmak istedikleri, gelecekte olmalarını arzu ettikleri, ulaştıklarında önemli faydalar sağlayacakları bir vizyondur. Bu vizyon, Almanya Hükümeti tarafından üretim ve sanayi alanında ileriye gitmek, daha verimli olmak ve müşterilerin isteklerine daha iyi cevaplar verebilmek adına ortaya konmuştur. Bu vizyona göre, E4.0 çeşitli teknolojik gelişmelerin birleşimidir, çatı bir kavramdır (Stock ve Seliger, 2016). Bu çatı altında yer alan teknolojiler ile üretimin daha hızlı, esnek, verimli ve kişiselleştirilmiş olması hedeflenmektedir (Santos vd., 2017).

E4.0'a tamamen adapte olan, geçen ve süreci tamamlayan henüz hiçbir ülke bulunmamaktadır. Almanya, Çin, ABD gibi çok iyi durumda olan ülkeler olmasına rağmen tam bir geçişten bahsedilememektedir. Bunun başarılabilmesi için, ülke içerisindeki işletmelerin tamamının E4.0'a hazır olması, işletmelerin, insanların ve şehirlerin "akıllı" niteliğine sahip olmaları gerekmektedir. İlk aşamada, ülkelerin hedefleri işletmelerinin E4.0 için hazırlık ve yatırım yapması olmaktadır. E4.0 teknolojik bileşenlerine sahip olmak için yapılan atılımlar, özellikle üretim ve sanayi alanında, önceliklidir. Bu nedenle, teknolojik bileşenler olan, siber fiziksel sistemler, nesnelerin interneti, arttırılmış gerçeklik, bulut bilişim, robotlar, büyük veri, 3 boyutlu yazıcı gibi teknolojilere (Hermann vd., 2016) yatırım yapmak, bununla birlikte işletme içinde görev tanımları, değer zincirleri, iş yapma şekilleri ve iş süreçlerini değiştirmek oldukça önemlidir. Bu devrimle ortaya çıkan baştan başa ya da uçtan uca entegresyon/dijitalleşme kavramı ile kast edilen de budur. İşletmede ki tüm süreçlerin, iş akışlarının ve iş yapış şekillerinin yeni sisteme göre değişmesi, tüm değer zincirlerinin birbiriyle bağlantıda olmasıdır (Kagerman vd., 2013). Bu sayede katma değeri yüksek sonuçlar yaratılabilir. Üstelik bu değer sadece işletme içinde de kalmayacaktır, bununla birlikte sektördeki diğer işletmelerle de bilgi paylaşımı, veri paylaşımı ve yeni gelişme ve değer firsatlarını ortaya çıkaracaktır.

E4.0'a geçmek ya da gerektirdiği teknolojilere sahip olmak, işletmeler için sermaye, bilgi ve nitelikli çalışanlar gerektirmektedir. Dolayısıyla, gerekli şartları sağlamak için işletmelerin bir hazırlık sürecinden geçmeleri lazımdır. Bu süreç büyük ölçekli işletmeler için nispeten daha kolaydır. Bilgi, sermaye, nitelikli çalışanlar ve teknolojiye sahip işletmelerin E4.0 dönüşümü KOBİ'lere nazaran daha kolaydır. Ayrıca, KOBİ'ler sadece Türkiye de değil, tüm dünyada benzer sorunları yaşamaktadır. Bilgi, teknoloji, finans ve çalışan konusunda sıkıntıları olan KOBİ'lerin E4.0 dönüşümünde büyük işletmelere göre daha fazla yardıma ihtiyac1 bulunmaktadır (Anderl ve Fleischer, 2016). Nitekim ülkemiz işletmelerinin \%99'unun KOBİ olduğu düşünüldügünde, bu durum Türkiye için kaçınılmazdır. KOBİ'lerin dönüşümü Türkiye için E4.0 başarısını temsil edecektir. Bu konuda hem hükümet, hem üniversiteler, hem danışmanlık kurumları hem de sivil toplum kuruluşları ortak bir akıl içerisinde hareket etmelidir. Akademik olarak, literatür ve örnek uygulamalar incelenerek, KOBİ'lere yol göstermek, model oluşturmak, bilgi vermek bizlerin görevidir. Nitekim, bu araştırmanın amacı da budur. Yapılan daha önceki araştırmalar incelendiğinde, KOBİ'lerin E4.0 farkındalık düzeyinin oldukça düşük olduğu görülmektedir. Birçok KOBİ, E4.0 kavramı ile henüz karşılaşmamış, belli bir kısmı duymuş ama tam olarak ne olduğunu bilmemekte, belli bir kısmı bilmesine rağmen yatırım yapmak ve sonuçlarını elde etmenin çok uzun soluklu olmasından dolayı kaçınmakta, çok az bir kısmı ise bilip uygulamaya çalışmaktadır. Dolayısıyla, bu farkındalı̆̆ı arttırmak ve bilgi eksikliğini gidermeye yardımcı olmak, Türkiye'nin E4.0'1 kaçırmaması ve KOBİ'lerin dönüşümü için oldukça önemlidir. 
Bu çalışma, literatürdeki E4.0 ve KOBİ'ler üzerine yapılmış olan birbirinden bağımsız çalışmaların sonuçlarını birleştiren, belli bir sistem içinde karşılaştırma yapan ve çıkarımlarda bulunan bir meta-sentez çalışmadır. Buna göre, ilk olarak KOBİ'ler ve E4.0 hakkında genel bilgiler verilmiş daha sonra ise, E4.0 için dönüşüm modelleri ve öneriler üzerinde durulmuştur. Literatürdeki önemli çalışmalar sentezlenerek, genel bir karşılaştırma yapılmış ve sonuçlar ortaya konmuştur.

\section{Küçük ve Orta Büyüklükteki İşletmeler (KOBI’ler)}

KOBİ'ler özellikle günümüzün değişen ve zorlaşan rekabet koşullarında, ekonominin canlılığını ve sürekliliğini sürdürmesinde önemli bir faktör olarak karşımıza çıkmaktadır. Öyle ki, Dünya bankasının tasvirine göre KOBI'ler “fidanlık" gibidir. KOBI'ler sadece kendileri üreterek ekonomik kalkınmaya fayda sağlamaz, büyük işletmelerinde ürettikleri ürünler için girdileri üreterek, onlara katkı sağlarlar. KOBİ'lerin tanımlamasına bakıldığında, çalışan sayısı ve net satış hasılatı gibi değerler göz önüne alındığında, hem ülkemizde hem de dünya da oldukça büyük bir paya sahip oldukları görülmektedir.

Tablo 1. KOBİ tanımı

\begin{tabular}{lcccc} 
Tanım Kriteri & Mikro İşletme & Küçük İşletme & Orta Ölçekli İşletme \\
\hline Çalışan sayısı & & $0-9$ & $10-49$ & $50-249$ \\
\hline $\begin{array}{l}\text { Yılık Net } \\
\text { Hasılatı }\end{array}$ & Satış & 3 Milyon TL & 25 Milyon TL & 125 Milyon TL \\
\hline Yıllık mali Bilançosu & 3 Milyon TL & 25 Milyon TL & 125 Milyon TL \\
\hline
\end{tabular}

Kaynak: KOBİ, 2020.

Tablo 1'de sınıflandırıldığ1 üzere, KOBİ'lerin tanımı, 2018'de değiştirilen “Küçük ve Orta Büyüklükteki İsletmelerin Tanımı, Nitelikleri ve Sinıflandırılması Hakkında Yönetmelik" de şu şekilde yapılmıştır; "Elli kişiden az yıllık çalışan istihdam eden ve yıllık net satış hasılatı veya mali bilançosundan herhangi biri yirmi beş milyon Türk Lirasını aşmayan işletmeler küçük işletme, İki yüz elli kişiden az yıllık çalışan istihdam eden ve yıllık net satış hasılatı veya mali bilançosundan herhangi biri yüz yirmi beş milyon Türk Lirasını aşmayan işletmeler ise orta büyüklükte ki işletmelerdir".

KOBİ'ler hem ekonomik hem de sosyal yönden avantaj sağlamaktadır. KOBI'ler krizlere karşı dayanıklıdır. Esnek yapılarından dolayı, krizle karşılaşıldığında gerekli değişimleri uygulayarak hayatta kaldıkları, ekonomik olarak ülkeye yardımcı oldukları görülmektedir. Bununla birlikte, çok çeşitli ve yüksek kaliteli ürünler üretmeleri, büyük işletmelere ara mal sağlamaları da önemli ekonomik avantajları içerisindedir. Sosyal açıdan bakıldığında ise, ülkedeki gelir dağılımının adaletli dağıtılmasında, istihdam düzeyinin artmasında, insanların yaşam kalitesi ve refah düzeyinin yükselmesinde, önemli bir paya sahiptir. Bunlara ek olarak, KOBI'lerin sahip olduğu avantajlar ve roller şu şekilde siralanabilir (Erdoğan, 2012, s.116-117);

- KOBİ'ler üretim değeri, miktar, istihdam, katma değer ve yatırım konularında olumlu bir etkiye sahiptir.

- KOBİler girişimcilerin iş hayatına girmesini kolaylaştırarak, toplumun yaratıcılığını teşvik eder.

- KOBİ'ler istihdamı arttırarak, yerel ve bölgesel kalkınmaya fayda sağlar.

- KOBİ'ler esnek üretim sistemine sahip oldukları için dijital dönüşümde avantaj sağlar.

- KOBİ'ler, gelir dağılımı adaletine, bölgesel gelir dağılımına iyileştirmelerde bulunur.

- KOBİ'ler mesleği öğrenme, yetişme ve nitelikli çalışanlara dönüşme noktasında önemli yerlerdir.

Nitekim, KOBİ Stratejisi Eylem Planı 2015-2018 'ten alınan verilere göre; KOBİ'ler Türkiye'de toplam işletmelerin \%99,9'nu, katma değerin \%55 'ini, yatırımların \%50 'sini, ihracatın \%59,2'sini toplam satışların \%65,5 'ini, ithalatın \%39,9'unu üstlenmektedir. Ayrıca, 
KOBİ'lerin Türkiye'de üretim değerindeki payı, \%56,2, maddi mallara ilişkin brüt yatırımdaki pay1, \%53,2, çalışanlar sayısı içerisindeki pay1, \%75,8'dir. Buna göre, KOBİ'lerin ülke ekonomisinde sayısal olarak büyüklüklerine ek olarak, istihdam, yatırım, ihracat, çalışan sayısı ve katma değer olarak ta çok önemli bir yerinin olduğu açıkça ortadadır.

KOBİ'ler üretim ekonomisinin itici gücüdür. Üretim sanayinin bel kemiği olan KOBİ'lerin E4.0 üzerindeki etkisi önemlidir. Tüm bu ekonomik ve sosyal üstünlüklerinin yanında büyük işletmelerle karşılaştırıldığında, KOBİ'ler farklı zorluklar ve engellerle karşı karşıya kalmaktadır. Büyük işletmelere göre geçiş sürecini daha sancılı yaşayan KOBİ'lerin E4.0'a yönelik paradigma geçişi desteklenmeli ve teşvik edilmelidir. Literatür incelendiğinde, bu geçişi başarıyla yöneten KOBİ'lere "KOBİ 4.0” atıfı yapılmaktadır (Mittal vd., 2018, s.194).

Tablo 2. KOBİ'ler ile çok uluslu işletmelerin tanımlayıcı özelliklerine göre karşılaştırılması

\begin{tabular}{|c|c|c|}
\hline Özellikler & KOBİ'ler & Çok Uluslu İşletmeler \\
\hline Finansal kaynaklar & Düşük & Yüksek \\
\hline İleri Üretim Teknolojileri Kullanımı & Düşük & (Çok) Yüksek \\
\hline Yazılım Yönü (veri analizi dahil) & $\begin{array}{l}\text { Düşük (Genellikle Özel } \\
\text { Çözümler) }\end{array}$ & $\begin{array}{l}\text { Yüksek (Daha Çok } \\
\text { Standart Çözümler) }\end{array}$ \\
\hline Araştırma ve Geliştirme & Düşük & Yüksek \\
\hline Ürün Uzmanlaşma Yapıs1 & Yüksek & Düşük \\
\hline Standartlaşmanın Önemi & Düşük & Yüksek \\
\hline $\begin{array}{l}\text { Organizasyon kültürü/ Liderin } \\
\text { Esnekliği }\end{array}$ & Düşük & Yüksek \\
\hline İşletme Stratejisi & İşletme Sahibinin Sezgileri & Piyasa araştırması ve doğru analiz \\
\hline Karar alma & $\begin{array}{c}\text { Liderle Sinırlı / Birkaç Bilgi } \\
\text { Taşıyıcısı }\end{array}$ & $\begin{array}{c}\text { Danışmanlar kurulu \& } \\
\text { (İç/dış) Danışmanlar }\end{array}$ \\
\hline Organizasyon yapıs1 & Daha az karmaş1k ve gayri-resmi & Karmaşık ve resmi \\
\hline İnsan Kaynakları Katılımı & Birden çok etki alanı & Özel Alanlar \\
\hline Bilgi ve Sektör Deneyimi & Özel bir alana odaklanmış & Farklı alanlar etrafında yayılmış \\
\hline $\begin{array}{l}\text { Üniversiteler/ Araştırma Kuruluşları } \\
\text { İşbirlikleri }\end{array}$ & Düşük & Yüksek \\
\hline Önemli faaliyetler & Diş kaynaklı & Kurum içinde \\
\hline Müşteri ve tedarikçi ilişkileri & Yüksek (Güçlü) & Düşük (Çok güçlü değil) \\
\hline
\end{tabular}

Kaynak: Mittal vd., (2018) s.195.

KOBİ'ler çok uluslu/büyük işletmelerle E4.0 açısından karşılaştırıldığında birçok özellikte daha zayıf kalmaktadır. Finans, ileri üretim teknolojileri, ar-ge, yazılım, üniversite işbirlikleri özellikle E4.0 için çok önemli olmakla birlikte KOBİ'lerde bu özelliklerin yetersiz kaldığı görülmektedir. Moeuf vd., (2017) araştırmalarında KOBİ'lerin ar-ge, yazılım ve uzman çalışan konusunda yoksun olduklarını ve daha fazla desteklenmeleri gerektiğini belirtmişlerdir.

\section{Kobi'ler ve Endüstri 4.0}

Endüstri tarihi açısından ilk kırılma noktası 18. yy çeyreğinde buhar makinesinin bulunmasıyla başlamıştır (Endüstri 1.0). 20. yy başlarında, Henry Ford'un montaj bantlarını kullanması ve seri üretim gerçekleştirmesi tüm dünyada büyük bir etki uyandırmıştır (Endüstri 2.0). Modern üretim hatlarının ilk defa kullanılmaya başlandığ olarak belirtilmiştir. 1970'lerden itibaren ise, endüstriyel otomasyon sistemleri üretim sisteminde kullanılmaya başlanmıştır (Endüstri 3.0). İnsan gücüyle yapılması zor, uzun ve tekrarlamalı işlerde PLC gibi endüstriyel sistemler kullanılarak daha hızlı, kaliteli ve düşük maliyetle üretim imkânı ortaya çıkmıştır (Apillioğulları, 2018, s. 9-10). 
Şekil 1. Endüstri 1.’dan Endüstri 4.0’a tarihsel gelişim

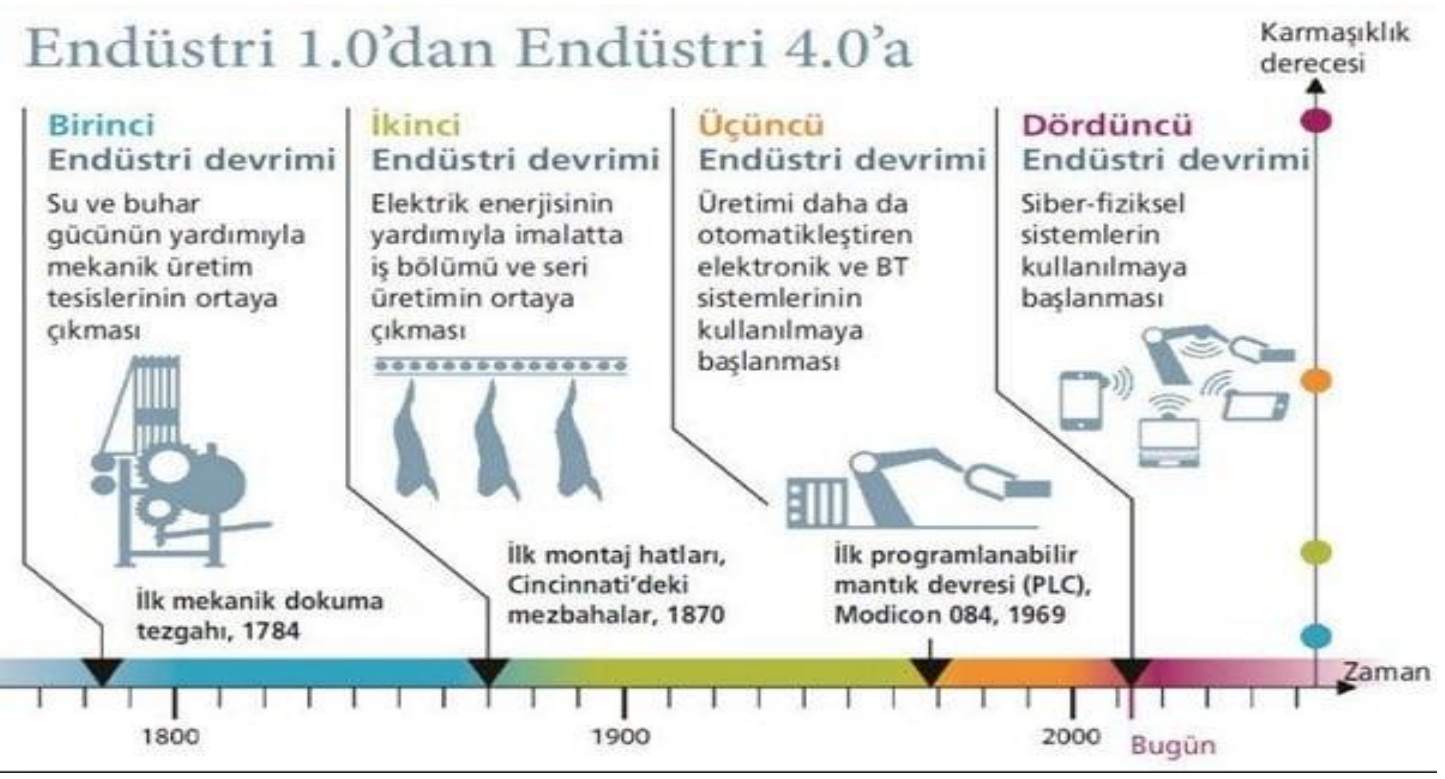

Kaynak: Garbie, (2016).

İlk üç sanayi devrimine bir buluş veya tek bir teknolojik tetikleyici sebep olmakla birlikte, E4.0 için birden fazla teknolojik inovasyon ve nedenler tetikleyici olmuştur. Buna göre, E4.0 kavramının doğuşunda iki temel neden bulunmaktadır. Birincisi gittikçe şiddeti artan küresel rekabet, ikincisi ise teknolojinin ilerlemesi ve buna bağlı olarak artan verimlilik potansiyelidir. Bu kavram ilk kez Alman Hükümeti tarafından 2011 yılında Hannover Fuarı'nda duyurulmuş, Almanya üretim endüstrisinin yüksek teknolojili üretim vizyonu ile ilişkilendirilmiştir (Mrugalska ve Wyrwicka, 2017, s. 469; Üstündağ ve Çevikcan, 2018). Bu vizyon doğrultusunda hareket etmek ve stratejiler geliştirmek adına E4.0 platformu kurularak faaliyetlerine başlamıştır. Kavramsal olarak bakıldığında, E4.0, bilgi ve iletişim teknolojilerinin üretim sistemlerine aşamalı olarak entegrasyonu anlamına gelmektedir (Niesen vd. 2016: 5066). $\mathrm{Bu}$ entegrasyonu başarabilmek için bir takım teknolojik bileşenlere ihtiyaç duyulmaktadır. $\mathrm{Bu}$ teknolojiler literatür incelendiğinde, E4.0'ın yapı taşları, teknolojik bileşenleri ya da unsurları gibi isimlerle açıklanmaktadır. Bunlar (Schwab, 2016; Roblek vd., 2016; Li vd. 2017; Lu, 2017; Grinin vd., 2017, s. 250; Devevas vd., 2017; Hermann vd., 2015; Hermann vd., 2016, s.105; Özdogan, 2017): Siber fiziksel sistemler, nesnelerin interneti, büyük veri, 3 boyutlu bask1, otonom robotlar, bulut bilişim, arttırılmış gerçeklik teknolojileridir.

2015 yılında Dünya Ekonomik Forumu'nda E4.0, birçok teknolojik bileşeni, veri alışverişlerini ve üretim teknolojilerini içeren bütüncül bir kavram olarak açıklanmış, geleceğin işgücünü, çalışanların becerileri ve iş yapma stratejilerini etkileyeceği belirtilmiş̧ir (Devezas vd., 2017; Schwab, 2016). E4.0 teknolojileri uygun kurumlar, standartlar ve normlarla birleştirilirse dünyanın her tarafındaki insanlar daha fazla özgürlük daha iyi sağlık, daha yüksek eğitim düzeyleri, ve istedikleri yaşam için daha fazla firsata sahip olacaklardır (Schwab ve Davis, 2019: ss. 28-29). İnsanların teknoloji ve uygulamalara erişim hızı eskiye oranla kıyaslandığında oldukça yüksektir. Örneğin, insanların ev telefonu ya da mobil telefona sahip olma hızları ile, bugün Facebook, Instagram gibi uygulamalara erişim hızı arasında çok büyük bir fark vardır. Aylar içerisinde milyonlarca kullanıcıya ulaşan CandyCrush uygulaması bunun bir göstergesidir (Schwab ve Davis, 2019, s.39).

E4.0 teknolojilerinin, çevremizdeki fiziksel dünyanın ayrılmaz birer parçası haline geleceği, bilim insanları tarafından belirtilmektedir. Bu teknolojilerin ayrıntılı tanımlamalarına bakmak konuyu daha iyi anlamak açısından önemlidir. Buna göre, siber fiziksel sistemler teknolojisi, sanal dünya ile gerçek dünyanın birleşimini ifade eder. Bilgi, alt sistemler, süreçler, 
makineler ve çalışanları birbirine entegre eden, küresel ağlar kurarak sanal dünya ile gerçek dünyayı birleştiren ve bundan faydalar sağlayan bir teknolojidir (Ivanov vd., 2016, s. 839). Bu teknoloji insanların rutin davranışlarının modellenmesi ve bu modellerin algoritmalara dönüştürülmesini sağlamaktadır. Böylece bilgisayar ortamına aktarılan bu modeller belli koşullar altında tahminleme yeteneği sağlamaktadır (Görçün, 2017, s.185). Nesnelerin interneti teknolojisi, isminden de anlaşıldığ 1 üzere nesnelerin birbirleriyle internet aracilığı ile bağlanmasını ifade eder. Buna göre kablolu veya kablosuz ağ yolu ile, akıllı özelliği olan makine ve nesnelerin birbirleri ile iletişim kurması, haberleşmesi ve buna göre hareket etmelerine nesnelerin interneti adı verilir (Zezulka vd., 2016, s.8).

Büyük veri teknolojisi, çağımızın petrolü olarak isimlendirilmektedir. Petrol kadar değerli olan bir şey var ise bu işlenmiş ve anlamlı hale dönüştürülmüş veridir. Bugün tüm dünyada insanlar sahip oldukları akıllı cihazlar ile işletmeler de sahip oldukları akıllı nesneler sayesinde sürekli veri üretmektedir. Bu veriler sayısal hale dönüştürülüp karar verme sürecinde kullanıldığında oldukça büyük faydalar sağlamaktadır. Nitekim, büyük veri, geniş, karmaşık ve yapılandırılmamış büyük miktardaki verileri anlamlı ve işlenebilir bir hale dönüştüren teknolojidir. Bu teknolojinin hedefleri, maliyetleri azaltmak, zaman tasarrufu, yeni büyük veri araçları geliştirmek ve destek yönetimi ve iş kararları olarak sıralanmaktadır (Banger, 2017, s.86). Veriler arttıkça, büyüdükçe ve karmaşıklaştıkça depolamak sorunu da beraberinde gelmektedir. Bu denli kıymetli olan ve büyük yer kaplayan veriyi depolama ihtiyacı ise bulut bilişimi ortaya çıkarmıştır. Bilginin depolanması, alt yapıların kurulması ve arka plandaki analizleri gerçekleştirmek temel görevleridir. (Dopico vd., 2016, s. 412). Böylece, bilgisayar özelliği olan cihazlar arasında ortak bilgi paylaşımı sağlanacak, bilgiye istenilen her yerden zaman ve mekân sınırı olmadan ulaşılabilinecektir.

Kaynakları etkin kullanmanın ve çevre duyarlılığının arttığı günümüz dünyasında yeni bir üretim şekli ortaya çıkmıştır, o da katmanlı üretimdir. Diğer adıyla 3 boyutlu yazıcı olarak ifade edilen katmanlı üretim teknolojisi üç boyutlu bilgisayar verisini, elle tutulabilecek gerçek nesnelere dönüştüren bir üretim şekli ve makinesidir. Hemen hemen bütün mekanik parçalar 3D tarafından üretilebilmektedir. Üstelik bu üretim gerçekleştirilirken işletmeyi makinelerle donatmak, büyük yatırımlar yapmak gibi hazırlıklarda gerekli değildir. Yazıcılara yüklenen programları güncellemek yeterlidir (Rifkin, 2015, s. 108).

E4.0 teknolojilerinde önemli bileşenlerden birisi de robotik uygulamalardır. Robotlar kendilerinde bulunan gömülü sensörler ve yazılımlar sayesinde verilen görevleri insan zekasını taklit ederek gerçekleştiren makinalardır. Sahip oldukları bağlantı sayesinde gerçek dünya ile iletişime girebilirler ve insanlarla birlikte çalışabilirler. Bu özellikleri ile robotlar akıllı ve bağlantılı makineler olarak kabul edilirler (Banger, 2017, s.71). Arttırılmış gerçeklik teknolojisi ise, sanal gerçeklik teknolojisinin zenginleştirilmiş halidir. Sanal ortamdaki verileri insan duygularını etkileyebilecek şekilde dönüştüren dijital ortamdaki canlandırmalardır (Siltanen, 2012, s.16). Böylece, gerçek dünya da yapılan işlerin, sanal ortamla birleştirilerek zenginleştirilmesini, çok fonksiyonlu hale gelerek, çalışanların yaratıcılık ve motivasyonlarını arttıran bir teknolojidir. Bu teknoloji, özellikle günümüz işletmelerinde iş eğitimlerinde, fabrika oryantasyon programlarında ve bir üretim sürecinin gösterilmesinde kullanılmaktadır.

Literatür incelendiğinde, bazı kaynaklarda bu teknolojilere, siber güvenlik, yapay zeka, yatay ve dikey entegrasyon, simülasyon gibi teknolojilerin eklendiği de görülmektedir. Fakat tüm teknolojiler birbirilerini kapsamakta ya da aynı çatının altında belirtilmektedir. Ayrıntılarıyla bakıldığında bu teknolojilerin bazılarının yeni bazılarının ise eskiden beri var olduğu bir gerçektir. Gerçek olan bir şey de şudur ki, uluslararası alanda ülkelerin rekabet avantajlarını kaybetmemesi için E4.0 dönüşümüne hazırlıklı olması gerekmektedir. Özellikle, Türkiye gibi işletmelerinin büyük bir çoğunluğunu KOBİ oluşturan ülkelerin bu konuda daha fazla çaba göstermesi ve engelleri ortadan kaldırması gerekmektedir. 
Yapılan araştbırmalarda, KOBI'ler E4.0'ın faydalarının ve getirilerinin farkında olmakla birlikte, E4.0'a neden geçmediklerine dair genel olarak şu sebepleri siralamaktadır (Pessl vd., 2017, s.195);

- Mevcut üretim altyapısının E4.0'a uygun olmayışı nedeniyle yüksek yatırım maliyetleri,

- $\quad$ E4.0'ın faydalarının eksik veya saydamlı̆̆

- $\quad$ Örgütsel değişebilirlik ve bilişim teknolojileri güvenliği ile ilgili endişeler.

Nitekim, bu konuda, Almanya'da KOBİ'lerin E4.0 karşısında, sahip oldukları güçlükler araştırılmış ve özetle şu bulgulara ulaşılmıştır (bilisim.com, 2018);

- $\quad$ KOBİ'lerin E4.0 uygulamalarını gerçekleştirecek altyapı, teknoloji ve yazılımlarına yatırım yapmamaları,

- $\quad$ KOBİ'lerin bölümler arası eşgüdümü sağlamakta güçlük çekmesi, bu nedenle, E4.0 stratejisini ve projelerini kurumun bütününde yönetmenin güçleşmesi,

- $\quad$ KOBİ'lerin radikal bir dönüşüme cesaret edememesi, bunun en önemli nedeninin ise E4.0 alanında çalışabilecek nitelikli personelin olmaması,

- $\quad$ KOBİ'lerin siber güvenlik konusunda zayıf olmalarıdır.

Sıralanan güçlüklere ilaveten yerli literatürde, Çevik (2019)'in KOBİ'lerde E4.0 uygulanabilirliği üzerinde yaptığı çalışmasında Türkiye'deki KOBİ'lerin \%66'sının E4.0'a hazır olduğu belirtilmiştir. Geriye kalan KOBİ'lerin E4.0 konusundaki zorluklarını ise; finansman yetersizliği, bilgi eksikliği, devlet teşviklerinin yetersizliği, nitelikli çalışan yokluğu, sistemin entegrasyonu, teknolojik alt yapıya sahip olmama, planlama yapmanın zorlukları, siber güvenlik endişesi ve yönetici-çalışan iliş̧kisinin sağlam olmaması gibi başlıklarda sıralamıştır.

E4.0 konusunda bu güçlüklere sahip olan KOBI'lerin sorunları sadece ülkemiz için değil tüm dünya ülkelerinin üzerinde durması gereken, önlem alınması, kaçırılmaması gereken bir durumdur. Bu konuda ilk önce devletlerin ve hükümetlerin daha sonrasında işletmelerin gerekli tedbirleri, stratejileri, yol haritaları ve kendilerine ait modellerini oluşturmaları gerekmektedir. $\mathrm{Bu}$ bağlamda MUSİAD tarafından hazırlanan, Türkiye'de işletmelerin/ KOBİ'lerin E4.0 yolculuğunda sahip güçlükler, zayıflıklar, firsatlar ve tehditler (SWOT) aşağıdaki tabloda gösterildiği şekilde sıralanmıştır. Buna göre, zayıf yönlerin dikkate alınıp güçlendirilmesi, fırsatların değerlendirilmesi ve tehditlere karşı gerekli önlemlerin alınması gerekmektedir.

Tablo 3. E4.0 modeli için Türkiye'nin SWOT analizi

\begin{tabular}{|c|c|}
\hline Güçlü & Zayıf \\
\hline $\begin{array}{ll}\text { - } & \text { Hızla büyüyen bir ekonomi } \\
\text { - } & \text { Talebi yüksek bir Pazar } \\
\text { - } & \text { Genç nüfus } \\
\text { - } & \text { Yaynolojiye yatkınlık mühendislik eğitimi } \\
\text { - } & \text { Sektörel yaygınlık } \\
\text { - } & \text { Diş pazarlara erişim kolaylı̆̆ } \\
\text { - } & \text { Yurt içi ulaşım kolaylığı } \\
& \text { Coklu kültüre yatkınlık }\end{array}$ & $\begin{array}{ll}\text { - } & \text { Nitelikli iş gücü } \\
\text { - } & \text { Akademik yapı } \\
\text { - } & \text { Sektörün kamuda tek bir muhatabının } \\
& \text { olmayışı } \\
\text { - } & \text { Yetersiz iç pazar büyüklüğü } \\
\text { - } & \text { Teknoloji geliştirme kültürü } \\
\text { - Isş hukuku } \\
\text { - } \quad \text { Bürokratik yaklaşım } \\
\text { - Proje finansman ihtiyacı } \\
\text { - }\end{array}$ \\
\hline Firsatlar & Tehditler \\
\hline $\begin{array}{ll}\text { - } & \text { Teşvikler } \\
\text { - } & \text { Yaygın teknokent yapısı, artan ARGE } \\
& \text { merkezleri } \\
\text { - } & \text { Ekonomik büyüme potansiyeli } \\
\text { - } & \text { Yatırımın ortamının devamı }\end{array}$ & $\begin{array}{ll}\text { - } & \text { Bürokrasinin sektöre yaklaşımı } \\
\text { - İstihdam baskısı } \\
\text { - } \\
\text { - } & \text { Ykademik eğitim kalitesi } \\
& \text { altında tutması }\end{array}$ \\
\hline
\end{tabular}


- 20.000'e yakın bilişim firması ile sektörün dinamik yapısı Birçok yabancı firmanın bulunduğu bir pazar

- Yazılım geliştirme potansiyeli

- Sektörel ișe başlama ilk yatırım oranının düşük olması

- Büyük projeler
- İhalelerde risk ve sektöre uygun ihale kanunu eksikliği Düşük karlılık ve haksiz rekabet

- Kamunun özel sektör ile rekabet etmesi

- Hukuki sorunlar

- Kamunun sektörde üretici olarak yer almas1

Kaynak: Türkiye Bilişim Derneği (2016), s.11.

KOBİ'lerin E4.0 konusunda tehditlerini ve zorluklarını ortaya koyan Mittal vd. (2018) alana önemli bir katkı sunmuştur. Yine Çevik (2019)'in yaptığı çalışmada ise KOBI'lerin henüz bu değişim sürecine birçok yönden hazır olmadığını, bütçe, bilgi eksikliği ve teknolojik alt yapı eksikliğinden dolayı sorun yaşadıklarını belirtmiştir. Benzer olarak Safar vd. (2018) KOBİ'lerin E4.0 için yazılım ve teknolojik alt yapı konusunda önemli eksikliklerinin olduğunu çalışmalarında belirtmişlerdir. Yiğitol vd. (2020) KOBİ'lerin teknoloji seviyelerini belirleme üzerine yaptıkları çalışmalarında, Türkiye'deki işletmelerin teknoloji kullanım düzeyinin çok düşük, temel seviyede ve E3.0 seviyesinde teknolojileri kullandıklarını ortaya koymuşlardır. Çalış Duman (2020) yaptığı çalışmasında ise, Türkiye'de büyük ve çokuluslu işletmelerin E4.0 konusunda daha iyi bir yerde olduğu, buna rağmen KOBİ'lerin E4.0 konusunda başlangıç seviyesinde olduğu görülmektedir. KOBİ'ler için bu araştırma çerçevesinde en önemli kısıtlar nitelikli çalışan yokluğu ve bilgi eksikliği olmuştur. Bunlarla birlikte, zayıflıklara rağmen KOBİ yöneticilerinin de E4.0 farkındalığ yüksektir. Kamber ve Bolatan (2019) Türkiye'deki üretim işletmeleri üzerine yaptıkları araştırmalarında, yöneticilerin E4.0'ın KOBİ'lerin üretiminde katma değeri yükselteceğine dair hem fikir olduklarını belirtmiştir. Bu noktada KOBI'lerin beklentileri devlet desteği ve teşvikler olmuştur.

\section{Kobi'ler için Endüstri 4.0 Olgunluk Modeli}

Nasıl E4.0'a geçilir, nasıl yapılır? Sorusunun cevabı literatür incelendiğinde ve uygulayan örnekler incelendiğinde, rehber niteliğinde dört tasarım ilkesi belirlenmiştir (Hermann vd. 2016, s. 3932); bağlantılılık, bilgi şeffaflığı, özerk kararlar ve teknik destek. Buna göre, E4.0'a geçiş yapmak isteyen işletmelerde bağlantılılık kapsamında, çalışanlar, makinalar ve cihazlar internet alt yapısı ile birbirine bağlı olmalıdır. Makineler arası iletişim ya da makine insan iletişiminin sağlandığı bu işletmelerde çalışanlar ve makineler uyumlu bir şekilde çalışabilir. Bilgi şeffaflığı kapsamında, gerçek zamanlı verilerin sanal ortamda ikizleri oluşturularak, tüm iş süreçleri bilgisayar ortamından anlık olarak izlenebilir. $\mathrm{Bu}$ durum kullanıcılara bilgilerin istenildiği anda, istenilen yerde erişimini kolaylaştırır. Bilgilerin şeffaflı̆̆ı, çalışanların tüm süreçlerden haberdar olmasını, daha isabetli karar vermesini ve üretkenliği arttırır. Böylece, sadece olağanüstü durumlar hariç, çalışanlar özerk kararlar verebilir. Çalışanların süreçlerden haberdar olması, karar verme konusundaki özgürlükleri yaratıcılıklarını ve örgüte ait bağlılıklarını arttırmaktadır. Son temel prensip olan teknik destek kısmında ise, KOBİ'lerin gerek akıllı cihazlar gerekse işbirlikçi işletmeler tarafından, bilinçli kararlar alabilmelerini ve acil sorunlarını kısa sürede çözebilmelerini sağlamak için bilgiyi anlaşılabilir bir şekilde toplama ve görselleştirmeleri konusunda yardım almaları gerekmektedir.

Tasarım ilkelerinden yola çıkarak, KOBİ'lerin dijital dönüşümü ya da E4.0 teknolojilerine sahip olması için hazırlanan yol haritalarında şu adımlara rastlanmaktadır (Banger, 2018); iş planına odaklanma, hedef pazarı dikkate alma, dönüşüm hedeflerini ürün ve hizmetler ile ilişkilendirme, çevreyi ve rakipleri analiz ederek plan hazırlama, uygulama planını belirleme ve gerçekleştirme ve sonuçları izleme şeklindedir. Pessl vd. (2017) ise E4.0'a ulaşmak için altı adımdan oluşan bir yol haritası ortaya koymuştur. Buna göre; ilk olarak mevcut durumun ve çevrenin analizi, daha sonra E4.0 olgunluk modelinin oluşturulması, amaçlanan durumların tanımlanması, amaçların ve hedeflerin gerçekçi olarak ortaya konması, karar verme ve uygulamaya geçiş ve son olarak projelere başlangıç olarak belirtmişlerdir. 
Her işletmenin E4.0 yolculuğu farklıdır. Bunun nedeni işletmenin örgüt yapısı, yöneticileri, çalışanları ve örgüt kültürünün farklı olmasından kaynaklanmaktadır. Bu durum hazırlanacak olan yol haritasının adımlarını da şekillendirmektedir. İşletmelerin rakipleri, içinde bulundukları pazar yapısı, sektör, sahip olduğu kaynaklar dikkate alınarak, dönüşümü başlatacak planların ve süreçlerin hazırlanması gerekmektedir. Bu hazırlık sürecinde dikkat edilmesi gereken bir takım unsurlar bulunmaktadır. Bunlar (The Brand Age, 2017);

- Platformlar ve çalışma gruplarının kurulması

- Odak sektörlerin belirlenmesi, özellikle Türkiye'nin E4.0 konusunda öncelikli sektörlerinin belirlenmesi

- KOBİ'lerin Ar-Ge çalışmaları kapsamına alınması

- KOBI'lere tasarım hizmetlerine ulaşım ve dahil olma ortamı yaratılması

- Bilişim teknolojilerinin yakından takip edilmesi, şeklinde sıralanabilir.

E4.0 olgunluk modeli ortaya konulurken, işletmelerin kendi mevcut durumu analizlerinde hangi konulara bakılması gerektiğine dair Alman Ulusal Bilim ve Mühendislik Akademisi (ACATECH) tarafından hazırlanan "E4.0 Olgunluk Endeksi" çalışması örnek teşkil edebilir. Nitekim ACATECH E4.0 devriminde ilk ve en önemli çalışmaları yapan kurumdur.

Şekil 2. E4.0 olgunluk endeksi bileşenleri

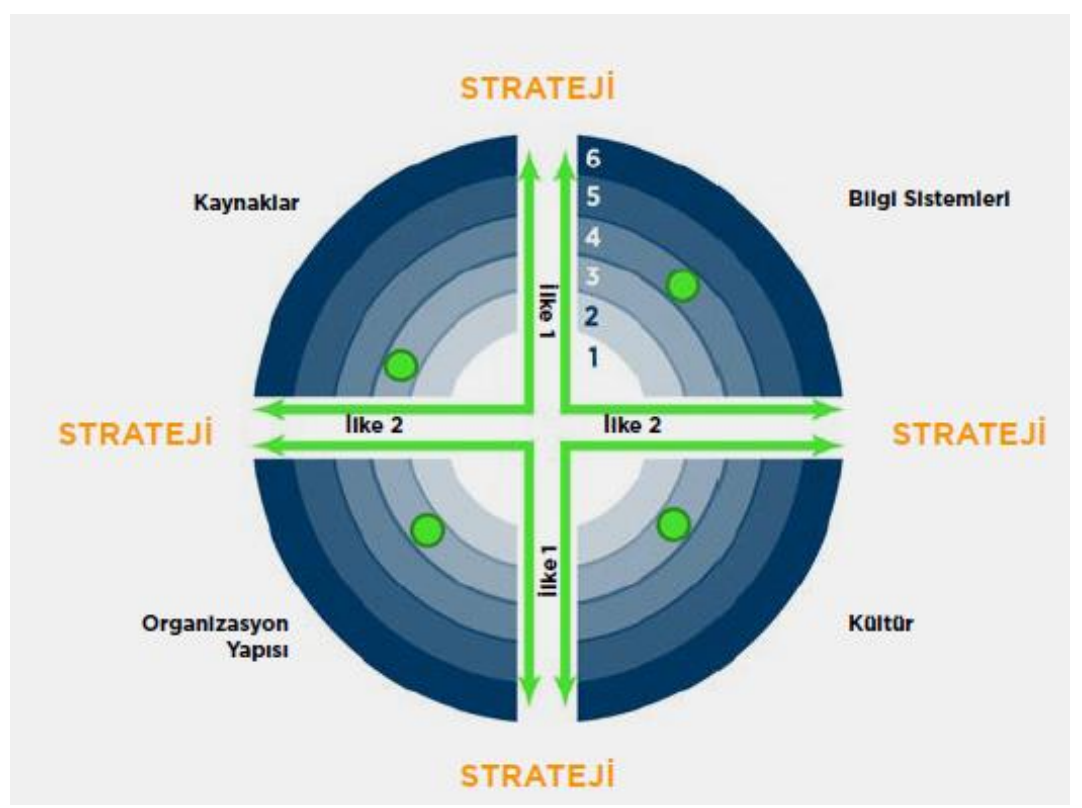

Kaynak: Schuh vd., (2017), s.19.

E4.0 Olgunluk Endeksi'nde işletmelerin E4.0 konusunda kendi durumlarını tespit etmelerine yönelik dört ana boyut altında bakılması gereken otuzüç alt başlık belirtilmiştir. Bu boyutların incelenip stratejilerin buna göre hazırlanması gerekmektedir. Bu boyutlar şu şekilde siralanabilir (Schuh vd., 2017, s.19-35);

- Bilgi sistemleri (bilgi işleme, esnek bilgi teknolojileri altyapısı, entegrasyon, yatay ve dikey entegrasyon-data yönetimi veri analizi, ilişkilendirilmiş veri girişi, uygulama türüne göre özelleştirilmiş kullanıcı ara-yüzleri, veri standardizasyonu, siber güvenlik). E4.0 konusunda en somut adım olarak ilk akla gelen bilgi sistemleridir, fakat E4.0 teknolojilerine sahip olmak tek başına yeterli değildir.

- Kaynaklar (dijital kapasite, dijital kabiliyetler, sensörler aracıllğıyla verilerin elde edilmesi, elde verilerin otonom analizleri ve işlenmesi, etkin haberleşme, görev odaklı arayüz tasarımı). İşletmenin kaynaklarının, çalışanlarının ve iletişim kanallarının yeni sürece uyumlu hale getirilmesi gerekmektedir. 
- Organizasyon yapısı (çevik yönetim, değer zinciri işletmeler arası iş birliği, organik organizasyon, esnek örgütler, karar alma yönetimi, motivasyon sistemleri, müşteri odaklılık, iş ağı ile ortak çalı̧̧ma).

- Kültür (açık örgüt iklimi, yeniliğe açıklık, öğrenen organizasyon, sürekli gelişimi demokratik liderlik tarzı, istatistiksel veri tabanlı öğrenme, bilgi paylaşımı ve şeffaflık) dür. Özellikle KOBI'lerde işletme yöneticilerinin ve girişimcilerinin E4.0'dan haberdar olmamaları ya da deneyimlerinin olmaması teknolojilere sahip olmada ve değişime karşı isteksiz olmalarına neden olmaktadır (Banger, 2018, s. 360).

KOBİ'lerin dönüşümü sırasında stratejilerini bu dört boyuta göre oluşturmaları ilk önce bilişim alt yapısı ve kaynak donanımını tamamlayarak örgüt yapıs1 ve kültürünü E4.0 sürecine uyumlaştırması gerekmektedir (Schuh vd., 2017, s. 16-18). Çünkü, E4.0 sadece makine ve ekipman gibi somut kaynakların değil, aynı zamanda çalışanların nitelikleri, örgütün kültürü, sahip olduğu yapı ve iklim gibi soyut kaynaklarını da kapsayan ve değiştiren bir devrimdir. Ayrıca, KOBİ'ler E4.0 yol haritasını hazırlarken, işletmenin organizasyon yapısına, finansal yapısına, çalışanların niteliklerine ve kültüre bağlı olarak hazırlaması gerekmektedir. Sektördeki bazı işletmeler kaynaklar ve sahip oldukları teknolojilerle E4.0'a daha kolay uyum sağlarken, bazı işletmeler daha zor bir süreç yaşayabilir. Bu aşamada KOBİ'ler mevcut durumlarına bakarak E4.0 konusunda olgunluk düzeylerini ölçümleyebilir. Tablo 4 ve Tablo 5 'te Anderl ve Fleischer (2016) tarafından KOBİ’lerin olgunluk düzeyini gösteren çalışmaları özetlenmiştir.

Tablo 4'te ürün temelli E4.0 olgunluk düzeyi tablosunda sorulması gereken soru şudur: E4.0 işletmelerin ürün geliştirmesine hangi katkıları sağlayabilir? Bu katkılar müşterilere nasıl bir katma değer yaratabilir (Anderl ve Fleischer, 2016, s. 13)? KOBİ'ler E4.0 teknolojilerine yatırım yapmasına bağlı olarak, ürün performansında, kalitesinde ve müşteri geri bildirimlerinde olumlu artışlar beklemektedir. Nitekim, örnek işletmeler dikkate alındığında, olumlu artışların olduğu görülmektedir. Buna göre, KOBİlerin olgunluk düzeylerini aşama aşama gerçekleştirerek dijital dönüşümü sağlaması oldukça önemlidir. 
Tablo 4. KOBİ'lerin ürün temelli Endüstri 4.0 olgunluk düzeyi

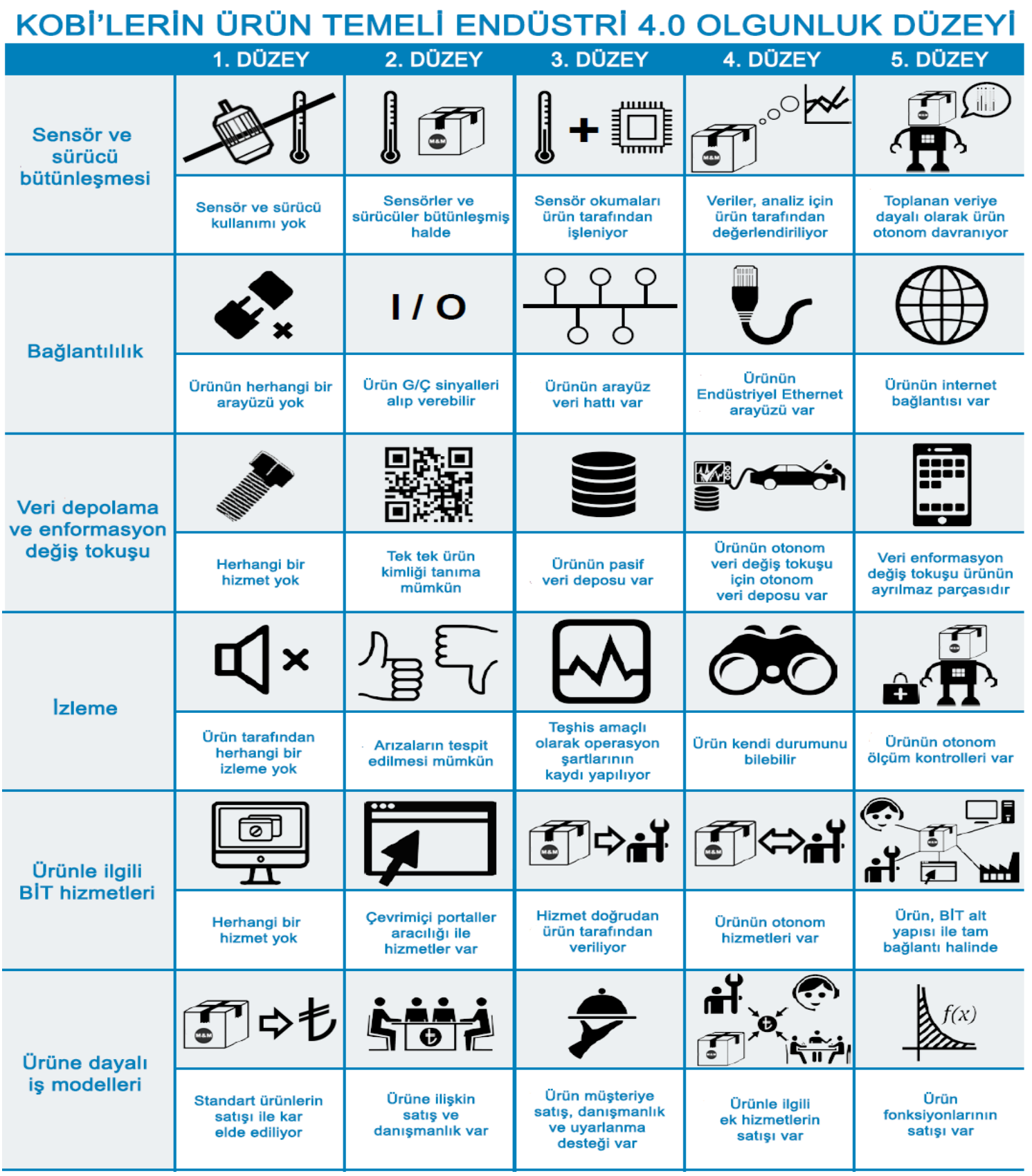

Kaynak: Anderl ve Fleischer, (2016), s. 9; Banger, (2018), s. 362. 
Tablo 5. KOBI'lerin üretim temelli Endüstri 4.0 olgunluk düzeyi

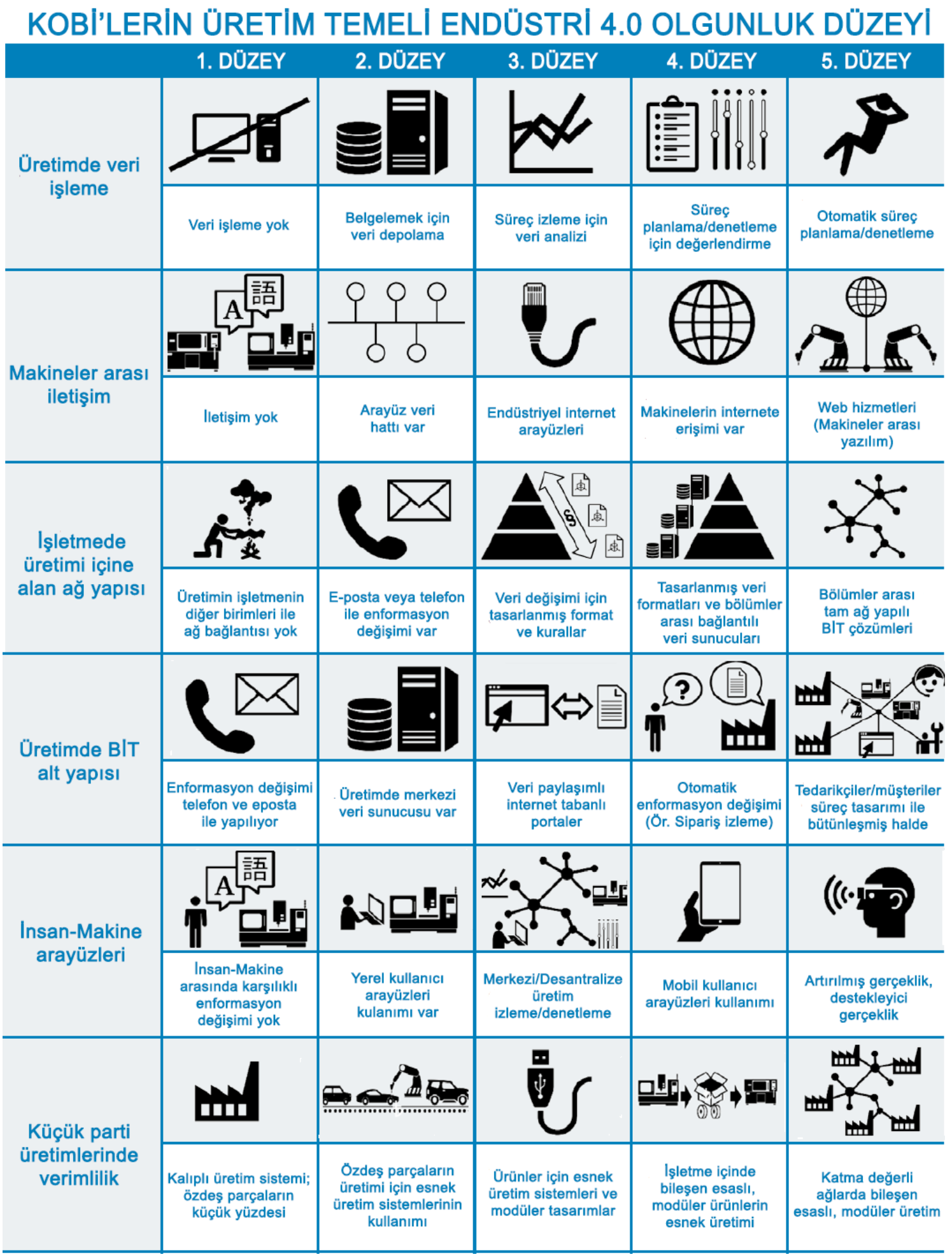

Kaynak: Anderl ve Fleischer, (2016), s. 9; Banger, (2018), s. 363.

Tablo 5'te KOBİ'lerin üretim temelli E4.0 olgunluk düzeyi belirlenmesinde ise, temel soru E4.0 teknolojileri ile üretim süreçlerinin nasıl optimize edileceği ve maliyetlerin nasıl azaltılacağıdır? Üretim sürecinde veri işleme, makineler arası iletişim, işletmeler arası ağ işbirliği, bilgi ve teknoloji alt yapısı, insan-makine arayüzleri ve küçük parti üretimlerinde verimlilik özelliklere göre KOBİ'lerin düzeyleri ve durumları ortaya konmaya çalışılır (Anderl 
ve Fleischer, 2016, s.13). Buna göre işletmelerin aşama aşama gerçekleştirecekleri her bir düzey örgüt performansında olumlu iyileştirmeler yaratacağı E4.0'a geçişin faydalarından yararlanacağı süreci yansıtmaktadır. Bununla birlikte, farklı araştırmalarda olgunluk modelleri ortaya koyan çalışmaları incelemekte de fayda vardır. KOBİ'lerin E4.0 dönüşümünde Ganzarain ve Errasti (2016) üç aşamalı bir olgunluk modeli ortaya koymuştur. E4.0 vizyonu, E4.0 yol haritası ve E 4.0 projeleridir. Buna göre, KOBI'ler ilk olarak bir E4.0 için bir vizyon ve hedef belirlemeli buna göre stratejilerini ortaya koymalıdır. Daha sonra bu stratejiler doğrultusunda planlamalar yaparak bir yol haritası çizmeli ve projeler üretmelidir. Özellikle teknoloji bazlı bu projeler, E4.0 sürecine geçişte somut olan adımı oluşturmaktadır. AR-GE merkezi olan KOBİ'ler bu konuda daha avantajlıdır.

Tablo 6. E4.0 dönüşümü için olgunluk modeli

\begin{tabular}{|c|c|c|c|c|}
\hline & & Tasarlama & Etkinleştirme & Uygulama \\
\hline & Aşama (Başlangıç) & \multicolumn{3}{|c|}{ İşletmeye özgü E4.0 vizyonu mevcut değildir. } \\
\hline 2. & Aşama (Yönetme) & E4.0 vizyonu tasarlama & $\begin{array}{l}\text { Müşteri profilleri ve müşteri } \\
\text { beklentilerini tanımlama }\end{array}$ & $\begin{array}{l}\text { Öncelikli olmayan portföy } \\
\text { projeleri }\end{array}$ \\
\hline 3. & Aşama (tanımlama) & $\begin{array}{l}\text { E4.0 özel getirilerini ve } \\
\text { kaynaklarını anlamak ve } \\
\text { geliştirmek }\end{array}$ & $\begin{array}{l}\text { Müşteri profilleri, müşteri } \\
\text { beklentilerini ve değer } \\
\text { yargılarını tanımlama }\end{array}$ & $\begin{array}{l}\text { Projeleri değerlendirme, } \\
\text { kaynak ve işbirliği } \\
\text { ihtiyaçlarını tanımlama }\end{array}$ \\
\hline 4. & Aşama (Dönüşüm) & $\begin{array}{l}\text { E4.0 firsatlar haritasinı tarif } \\
\text { etme }\end{array}$ & $\begin{array}{l}\text { Müşteri profilleri, müşteri } \\
\text { beklentilerini, değer } \\
\text { yargılarını, teknolojileri ve } \\
\text { kaynakları tanımlama }\end{array}$ & $\begin{array}{l}\text { Eylem ve gelecek portföy } \\
\text { projelerini detaylandırma }\end{array}$ \\
\hline 5. & $\begin{array}{l}\text { Aşama (İşletme } \\
\text { Modeli Dönüşümü) }\end{array}$ & $\begin{array}{l}\text { E4.0 tarafindan gelecek } \\
\text { dönüşümleri } \\
\text { E4.0 vizyonuna sahip olma }\end{array}$ & $\begin{array}{l}\text { E4.0 İşletme Modeli, tüm } \\
\text { işletme süreçlerini E4.0'a } \\
\text { entegre etme. }\end{array}$ & $\begin{array}{l}\text { Projeleri hayata geçirme, } \\
\text { Risk=Getiri }\end{array}$ \\
\hline
\end{tabular}

Kaynak: Ganzarain ve Errasti (2016), s. 1126.

$\mathrm{Bu}$ modele göre, işletmeler ve her seviyede süreçler için tanımlanmış hedefleri ve uygulamaları benimseyerek, henüz E4.0 vizyonu bile olmayan birinci aşamadan olgunluk seviyelerine doğru ilerlemelidir (Ganzararin ve Errasti, 2016, s. 1125). Burada altını çizmekte fayda görülen konu şudur ki, işletmede en alttan en üste kadar tüm çalışanların ve yöneticilerin E4.0'dan haberdar olmaları, hedeflerine koymaları, örgüt içindeki kültür ve anlayışların bu hedefe göre şekillendirilmesi oldukça önemlidir. E4.0'1 benimsemeyen yöneticiler ve çalışanlar bu geçişin en önemli engelleri içerisindedir. Ayrıca, işletme teknolojilerini ve iş yapma şekillerini değiştirirken, değiştirilmesi gereken diğer bir husus da çalışanların nitelikleridir. Çalışanlar, Endüstri 4.0 sürecine uyumlu hale getirilmek için teorik ve uygulamalı eğitimlerle desteklenmelidir.

KOBİ'lerin E4.0 hazırlık süreci, modelleri ve yol haritaları ile KOBİ 4.0 yolculuklar1 başlamaktadır. KOBİ'ler büyük işletmelere nazaran E4.0'a geçişten somut faydalar sağlamayı beklemektedir. Bu konu da yapılan tüm çalışmalarda E4.0 teknolojilerine yatırım yapmanın örgüt performansını avrttıracağı açık bir şekilde ifade edilmektedir. KOBİ'lerin E4.0 konusundaki beklentileri ve elde etmek istedikleri faydalar Tablo 7'deki gibi özetlenebilir. 
Tablo 7. Endüstri 4.0'ın KOBİ'lerin iș modeli unsurları üzerindeki etkisi

\begin{tabular}{|c|c|c|}
\hline Değer Yaratma & Değer Sunma & Değer Elde Etme \\
\hline \begin{tabular}{ll} 
- & \multicolumn{1}{c}{ Üretim Ekipmanları } \\
- & Enerimlilik artışı tasarrufu \\
- & Yük dengelemesi \\
- & Üretim ekipmanının daha yüksek \\
hata direnci \\
- $\quad$ Üretim verilerine hızlı erişim \\
- $\quad$ Makine arıza izleme \\
- $\quad$ Kendinden kontrollü üretim \\
- $\quad$ Daha ḑirket içi üretim \\
- $\quad$ Daha kolay üretim bakımı \\
- $\quad$ Eski makinelerin güçlendirilmesi
\end{tabular} & 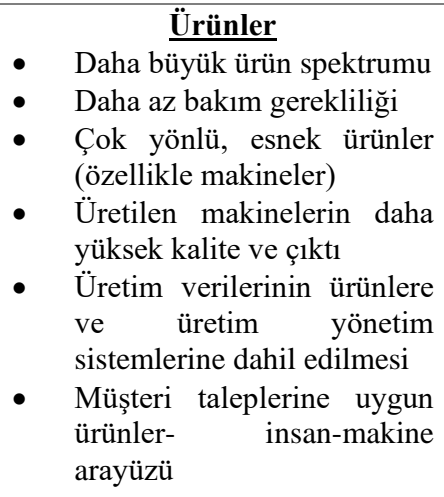 & $\begin{array}{l}\text { Müșteri Grupları } \\
\text { - } \quad \text { B2B müşteri bazında ele alınan } \\
\text { yeni müşteri grupları } \\
\text { - Yeni müşterileri elde etmeye } \\
\text { yoğunlaşma }\end{array}$ \\
\hline \begin{tabular}{ll} 
& \multicolumn{1}{c}{$\underline{\text { Issgücü̈ }}$} \\
- & Üretimde iş kıtlığının azaltılması, \\
- & Kalifiye personel \\
- & Düşük nitelikli ve yaşlı personelin \\
& daha iyi entegrasyonu \\
- & Yeni iş profilleri \\
- & Yeni işyerleri \\
- & Daha yüksek teknik uzmanlık ve \\
çalışan eğitimleri gereklilikleri \\
- & Teknoloji tabanlı eğitimler \\
- & Arıza tanıma desteği \\
- & Azalan üretim işi sayısı
\end{tabular} & \begin{tabular}{ll} 
& \multicolumn{2}{c}{ Hizmetler } \\
- & Makine güçlendirme \\
& hizmetleri \\
- & Durum izleme \\
- & Uzaktan bakım \\
- & Müşteriler için \\
& dijitalleştirme hizmetleri \\
- & Veri analizi hizmetleri \\
- & Üretim ve ürün \\
- & Simülasyonları \\
- & Mühal ürün geliştirme \\
& konfigürasyon hizmetleri
\end{tabular} & 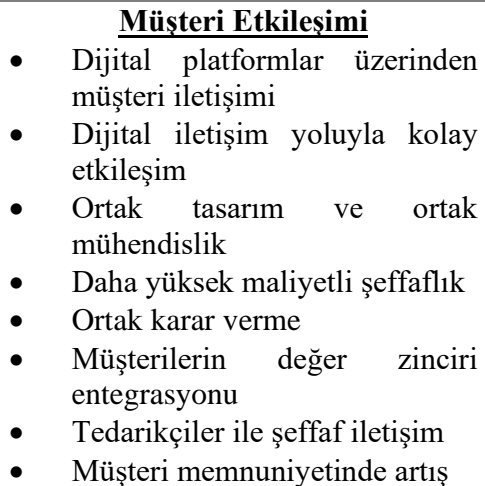 \\
\hline \begin{tabular}{ll} 
& \multicolumn{1}{c}{ Ortaklar ve tedarikciler } \\
- & Daha yüksek şirketler arası bağlantı \\
- & Değer tekliflerinin ortak tasarımı \\
- & Ortak veri analizi \\
- & Daha yüksek bilgi şeffaflığı \\
- & Daha yüksek teslimat güvenilirliği \\
- & Artan sanal ortaklıklar \\
- & Daha yüksek standim \\
\end{tabular} & & 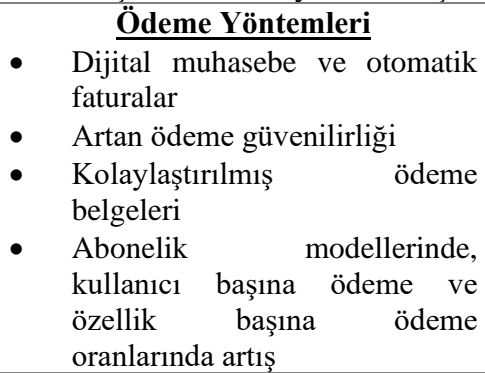 \\
\hline
\end{tabular}

Kaynak: Müller vd., (2018), s.6.

\section{Sonuç ve Öneriler}

Türkiye jeopolitik konumundan dolayı tarım, sanayi ve hizmet sektörlerinde oldukça önemli bir avantaja sahiptir. Genç nüfusu, dinamik demografik yapısı, teknolojiyi özümsemesi ve teknoloji kullanan nüfus sayısının oldukça yüksek olması Türkiye'nin cazibe oluşturan özellikleri durumundadır. Türkiye üretim konusunda önemli bir paya ve çeşitliliğe sahip olmasına rağmen, katma değeri düşük, ekonomik bedeli az ürünleri üretmektedir. Bu durum Türkiye'nin E4.0 konusunda önemli bir tehdididir. Türkiye E4.0 dönüşümünü sağlayarak bu tehdidi yok edip, katma değeri yüksek ürünler, daha az maliyetli üretim, esnek üretim, nitelikli çalışan faydalarını elde etmek istemektedir.

TÜBİTAK (2017) tarafindan sanayimizin dijital olgunluk seviyesini ortaya koymak amacıyla 1000 firmayla yaptığı araştırma sonuçlarına göre, Türkiye'de sanayinin dijital olgunluk seviyesi E2.0 ile E3.0 arasında yer almaktadır. Fakat her ne aşamada olunursa olunsun E4.0'ın kesinlikle kaçırılmaması gerektiği vurgulanmaktadır. Yapılan bazı araştırmalarda da, öğrenmeye, yeniliğe ve inovasyona daha yatkın olan KOBİ'lerin gerekli destek sağlanıp, önlemler alınırsa dönüşümünün daha kolay olacağı belirtilmektedir.

Türkiye ekonomisinin temelini KOBİ'ler oluşturmaktadır. \%1 lik bir kısımda yer alan büyük/çokuluslu işletmelerin üretim alanında payı yüksek olmakla birlikte E4.0'a geçiş 
konusunda da olgunluk düzeyleri yüksektir. E4.0 konusunda farkındalık düzeyleri ve olgunluk düzeyleri düşük olan KOBİ'lerin Türkiye sanayisinin ilerlemesinde ve rekabetçiliğinin arttırılmasında kritik bir rol üstlendiği açıktır. Geleceğin işletmelerinin akıllı işletmeler olduğu, yapılan araştırmalarda ve söylemlerde karşımıza çıkmaktadır. E4.0 dönüşümünü tamamlayan ya da teknolojilerini kullanan işletmeler diğer işletmeler karşısında rekabet üstünlüğüne sahip olacaktır. Hatta bazı söylemlerde değişime uyum sağlayamayan işletmelerin yok olacağ belirtilmektedir. Bu nedenle ülke ekonomimizin fidanlığı olan, can suyu olan KOBİ'lerin E4.0 yolculuklarında zayıf yönlerini güçlendirmek, tehditlerini yok etmek için ortak bir mücadele başlatılmalıdır. E4.0'ın getirilerinden faydalanmak için bir takım önlemler ve stratejiler oluşturulmalıdır. Bu önlemler şu şekilde sıralanabilir;

- KOBI'lerin dönüşümü ve E4.0'a geçişleri sadece kendi çabalarıyla mümkün olacak bir durum değildir. Bu konu da tüm paydaşlara, yöneticilere, devlete ve hatta bir birey olarak bizlere bile önemli roller düşmektedir. Özellikle altyapı ve eğitim sistemlerinin E4.0 sürecine uygun hale getirilmesi gerekmektedir. Popüler bir söylentiye göre, bugün doğan çocukların \%90'ının bugün hiç duyulmayan mesleklerde çalışacağı belirtilmektedir. Böyle bir düşünceye göre ilk önce eğitim sistemimizin E4.0'1n ihtiyac1 olan çalışanları ortaya çıkarabilecek şekilde düzenlenmesi gerekmektedir. Bu konuda yapılan çalışmalar literatür de Eğitim 4.0 olarak adlandırılmaktadır.

- Üreticiler, üretim süreçlerinde önceliklerini belirlemek ve işgücü yetkinliklerini geliştirmek zorundadırlar. Öncelikle esneklik, hız, verimlilik ve kalite gibi iyileştirilecek kilit alanlar belirlenmelidir. Ayrıca, E4.0'ın çalışanlar üzerindeki etkisi incelenmeli ve işgücü planlamaları yapılmalıdır. İşe alım ve mesleki eğitimler yeni içeriklere göre düzenlenmelidir (TUSİAD, 2016).

- Hükümet ve kamunun teknolojik altyapıyı, başta sabit ve mobil geniş bant hizmetleri başta olmak üzere iyileştirilmesi gerekmektedir. Teknolojik alt yapının işletmelerin ağa bağlı iş yapış süreçlerini ve veri akışlarını en hızlı ve en güvenilir şekilde oluşturmaları gerekmektedir (TUSİAD, 2016).

- Eğitim alanında, derslerin, mesleki eğitim ve yükseköğretim programlarının, çalışanların bilişim teknolojileri ile beceri ve yetkinliklerini arttıracak şekilde düzenlenmesi ve girişimci yaklaşımların güçlendirilmesi gerekmektedir (TUSİAD, 2016).

- KOBİ'lerin yeni teknolojiler, üretim/çalışma metotları ve daha yetkin işgücüne erişim gibi alanlarda gerekli yatırımları gerçekleştirmelerini mümkün kılmak için kurgulanmış bir teşvik sistemi hayati önem taşımaktadır. Özellikle bu konuda, E4.0 platformları, hibe destekleri, teknoloji transfer ofisleri, yol haritası oluşturmada danışmanlık firmaları gibi oluşumlara gidilmesi oldukça önemlidir.

- KOBI'lere rol model olacak E4.0'a uyumlu işletmelerin danışmanlık hizmeti vermesi tavsiye edilebilir. Nitekim Bilim Teknoloji ve Sanayi Bakanlığı (2018)'nın Türkiye'nin belirli illerinde model fabrika kurması planlanmış ve uygulamalarıyla hayata geçmeye başlamıştır. Sayıları çoğalan başarılı işletmeler KOBİ'ler için cesaret olacaktır.

- İçinde bulunduğumuz Covid-19 pandemi süreci bizlere çalışma hayatının ofislere sığdırılamayacağını göstermiştir. Özellikle KOBİ'lerin hayatta kalması bu süreçte Türkiye'nin temel sorunudur. Akıllı teknolojilere adapte olan, uzaktan çalışma imkanlarını sağlayabilen KOBİ'ler süreçten daha az zarar görmektedir. Bu nedenle E4.0'ın pandemi de dahil olmak üzere birçok sorun için çözüm olacağı açıktır. 


\section{Kaynakça}

Anderl, R. ve Fleischer, J. (2016). Guideline industrie 4.0: Guiding principles for the implementation of industrie 4.0 in small and medium sized businesses. Technical Repor: VDMA. Forum Industrie 4.0, Frankfurt, ISBN: 978-3-8163-0687-0.

Apilioğulları, L. (2018). Dijital dönüşümün yol haritası endüstri 4.0: Değişimin getirdikleri. İstanbul: Agora Kitaplığ1

Banger, G. (2016). Endüstri 4.0 ve akıllı işletme, Ankara: Dorlion Yayınları.

Banger, G. (2017). Endüstri 4.0 ekstra, Ankara: Dorlion Yayınları.

Banger, G. (2018). Endüstri 4.0 uygulama ve dönüşüm rehberi. Ankara: Dorlion Yayınları.

Çalış Duman, M. (2020). Endüstri 4.0 teknoloji bileşenlerinin örgütsel performansa etkilerini belirlemeye yönelik bir araştırma. (Yayımlanmamış doktora tezi), İnönü Ünv. SBE. Malatya.

Çevik, D. (2019) KOBİ'lerde sanayi 4.0'ın uygulanabilirliği ve yönetici bakış açılarının değerlendirilmesi. IBAD, 4(2), 277-291.

Devezas, T., Leitao J. ve Sarygulov A. (2017). Industry 4.0 entrepreneurship and structural change in the new digital landscape, Switzerland: Springer International Publishing AG.

Dopico, M., Gomez, A. D. L Fuente, D., García, N., Rosillo, R. ve Puche, J. (2016). A vision of industry 4.0 from an artificial intelligence point of view. Int'l Conf. Artificial Intelligence, ICAI'16, 407-413.

Erdoğan, Z. (2012). Girişimcilik ve KOBI'ler, Bursa: Ekin Yayıncılık

Endüstri 4.0 ve KOBİ'ler, https://bilisim.com.tr/haberler/endustri-40-ve-kobi-ler-291, (Erişim tarihi:12.10.2020).

Ganzarain, J. ve Errasti, N. (2016). Three stage maturity model in sme's toward industry 4.0. Journal of Industrial Engineering and Management, 9(5), http://dx.doi.org/10.3926/jiem.2073.

Garbie, İ. (2016). Sustainability in manufacturing enterprises; concepts, analyses and assessments for industry 4.0. Switzerland: Springer International Publishing.

Gilchrist, A. (2016). Industry 4.0: The industrial internet of things. New York: Springer Publishing, Apress Media.

Görçün, Ö. F. (2017) Dördüncü sanayi devrimi, endüstri 4.0, İstanbul: Beta Yayınc1l1k.

Grinin, L.E., Grinin, A.L. ve Korotayev, A. (2017). Forth-coming kondratieff wave, cybernetic revolution and global ageing. Technologial Forecasting Social Change. 115(C), 52-68.

Hermann, M., Pentek T. ve Otto B. (2016). Design principles for industrie 4.0 scenarios. 49th Hawaii International Conference on System Sciences, 3929-3937.

Hermann, M., T. Pentek, ve B. Otto, (2015). Design principles for industrie 4.0 scenarios: A literature review. Working Paper, Dortmund:Technische Universität.

Ivanov, D., Sokolov B. ve Ivanov M. (2017). Schedule coordination in cyber-physical supply networks Industry 4.0. IFAC-PapersOnLine, 49(12), 839-844. 
Kagermann, H., Wahlster W. ve Helbig J. (2013). Recommendations for 1mplementing the strategic 1nitiative industrie 4.0. ACATECH-National Academy of Science and Engineering.

Kamber, E. ve Bolatan, G. İ. S. (2019). Endüstri 4.0 Türkiye farkındalığı. Mehmet Akif Ersoy Üniversitesi Sosyal Bilimler Enstitüsü Dergisi, 11(30), 836-847.

KOBİ (2020). KOBİ tanımı, http://www.kobi.org.tr/index.php (Erişim Tarihi: 31.07.2019).

KOBİ Stratejisi ve Eylem Planı (2015-2018), KSEP, https://www.kosgeb.gov.tr/Content /Upload/Dosya/KSEP\%20G\%C3\%BCncellenen\%20Eylem\%20Plan\%C4\%B1\%2020152018_06_05_2016.pdf. (Erişim tarihi: 04.04. 2021).

Li, X., Li D., Wan J., Vasilakos, A.V., Lai C.F. ve Wang S. (2017). A review of industrial wireless networks in the context of Industry 4.0. Wireless Network, 23, 23-41. do1 10.1007/s11276-015-1133-7.

Lu, Y. (2017). Industry 4.0: A survey on technologies, applications and open research issues. Journal of Industrial Information Integration, 6, 1-10.

Mittal, S., Khan, M. A., Romero, D., ve Wuest, T. (2018). A critical review of smart manufacturing and Industry 4.0 maturity models: Implications for small and medium-sized enterprises (SMEs). Journal Of Manufacturing Systems, 49, 194-214.

Moeuf, A., Pellerin R.S., Lamouri S., Giraldo T. ve Barbaray R. (2017). The industrial management of Sme's in the era of Industry 4.0. International Journal of Production Research, 56(3), 1118-1136, do1:10.1080/00207543.2017.1372647.

Mrugalska, B. ve Wyrwicka M.K. (2017). Industry 4.0-towards opportunities and challenges of implementation. 24th International Conference on Production Research, doi: 10.12783/dtetr/icpr2017/17640.

Müller, J. M., Buliga O. ve Voigt K. (2018). Fortune favors the prepared: How SME's approach business model innovations in Industry 4.0. Technological Forecasting and Social Change, $132,2-17$.

Niesen, T., Fettke P. ve Peter L. (2016). Towards an integrative big data analysis framework for data-driven risk management in industry 4.0. 49th Hawaii International Conference on System Sciences, 5065-5074.

Özdoğan, O. (2017). Endüstri 4.0, dördüncü sanayi devrimi ve endüstriyel dönüşümün anahtarları, İstanbul: Pusula 20 Teknoloji ve Yayıncılık A.Ş.

Pessl, E., Sorko S.R. ve Mayer B. (2017). Roadmap industry 4.0- 1mplementation guideline for enterprises. International Journal of Science, Technology and Society, 5(6), 193-202.

Rifkin, J. (2015). Nesnelerin interneti ve iş birliği çağl, (L. Göktem. Çev.), İstanbul: Optimist Yayınları.

Roblek, V., Meško M. ve Krapež A. (2016). A complex view of industry 4.0. Sage Open. 1-11, do1: $10.1177 / 2158244016653987$.

Safar, L., Sopko, J., Bednar, S. ve Poklemba R. (2018). Concept of sme business model for industry 4.0 environment. TEM Journal, 7(3), 626-637, do1: 10.18421/TEM73-20. 
Santos, M.Y., Sá J.O., Andrade C., Lima F.V., Costa E., Costa, C., Martinho B. ve Galvão J. (2017). A big data system supporting Bosch Braga 1ndustry 4.0 Strategy", International Journal of Information Management, 37, 750-760.

Schuh, G., Gausemeier J. ve Wahlster W. (2017). Industrie 4.0 maturity index. ACATECH, Germany.

Schwab, K. (2016). Dördüncü sanayi devrimi, World Economic Forum, (Z. Dicleli. Çev.), İstanbul: Optimist Yayınları.

Schwab, K. ve Davis N. (2019). Dördüncü sanayi devrimini şekillendirmek, İstanbul: Optimist Yayınları.

Siltanen, S. (2012). Theory and applications of marker-based augmented reality. Technical Research Centre of Finland: Julkaisija Utgivare-Publisher.

Stock, T. ve Seliger G. (2016). Opportunities of sustainable manufacturing in industry 4.0. Procedia CIRP, 40, 536-541.

The Brand Age (2020). KOBİ'ler endüstri 4.0'ın en önemli aktörü olacak, https://www.thebrandage .com/kobiler-endustri-40in-en-oenemli-aktoru-olacak), (Erişim tarihi: 12.11.2020).

TUSİAD ve The Boston Consulting Group (BCG) (2016). Türkiye'nin küresel rekabetçiliği için bir gereklilik olarak Sanayi 4.0: Gelişmekte olan ekonomi perspektifi. İstanbul: TÜSİAD$\mathrm{T} / 2016-03 / 576$.

Türkiye Bilişim Derneği (2016) Bimy’23, bilişimle kalkınmada sanayi 4.0. Etkinlik Sonuç Raporu, 23. Bilgi İşlem Merkezi Yöneticileri Semineri, Ankara.

Üstündağ, A. ve Çevikcan E. (2018). Industy 4.0: Managing the dijital transformation. Switzerland: Springer International Publishing.

Yiğitol B., Güleş H.K. ve Sarı T. (2020). Endüstri 4.0 dönüşüm sürecinde, KOBİ’lerin teknoloji seviyelerinin belirlenmesi: Konya imalat sanayi örneği. International Journal of Advances in Engineering and Pure Sciences, 32(3), 320-332.

Zezulka, P., Marcon, I. Vesely ve Sajdl, O. (2016). Industry 4.0-an introduction in the phenomenon. IFAC-PapersOnLine, 49(25), 8-12.

\section{ETIKK ve BİLIMSEL İLKELER SORUMLULUK BEYANI}

$\mathrm{Bu}$ çalışmanın tüm hazırlanma süreçlerinde etik kurallara ve bilimsel atıf gösterme ilkelerine riayet edildiğini yazar(lar) beyan eder. Aksi bir durumun tespiti halinde Afyon Kocatepe Üniversitesi Sosyal Bilimler Dergisi'nin hiçbir sorumluluğu olmayıp, tüm sorumluluk makale yazarlarına aittir. 